\title{
ANALISIS KINERJA KEUANGAN PADA PT. PEGADAIAN \\ (PERSERO)CABANG TALASALAPANG DI KOTA MAKASSAR
}

\author{
Nur Hajar Aswad \\ (hajar203.nha@gmail.com) \\ Institut Bisnis dan Keuangan Nitro Makassar Jl. Prof Abdurahman Basalamah No. 101
}

90231

\begin{abstract}
ABSTRAK
Penelitian ini bertujuan untuk mengetahui kinerja keuangan pada PT.Pegadaian (Persero) Cabang Talasalapang di Kota Makassar. Jenis penelitian ini adalah kuantitatif deskriptif yaitu menjelaskan rasio keuangan yang terdiri dari rasio likuiditas, rasio solvabilitas, rasio aktivitas, dan rasio profitabilitas yang terjadi dalam perusahaan pada tahun 2014-2017. Populasi dalam penelitian ini adalah laporan keuangan PT. Pegadaian (Persero) Cabang Talasalapang di Kota Makassar selama empat tahun terakhir (20142017) sekaligus menjadi sampel pada penelitian ini. Pengumpulan data dilakukan dengan teknik wawancara dan dokumentasi.

Hasil penelitian menunjukkan bahwa kinerja keuangan pada PT.Pegadaian (Persero) Cabang Talasalapang di Kota Makassar selama empat tahun terakhir dalam kondisi baik. Pengukuran kinerja keuangan dengan menggunakan Rasio likuiditas yang terdiri dari current ratio dan quick ratio menunjukkan kinerja keuangan sangat baik karena berada di atas rata-rata standar industri. Namun cash rasio pada tahun 2015 dinilai dalam keadaan kurang baik karena dibawah rata-rata standar industri disebabkan oleh meningkatnya hutang lancar dibandingkan kas pada tahun sebelumnya. Rasio solvabilitas yang terdiri dari debt to assets ratio perusahaan pada tahun 2015-2017 mengalami fluktuasi, jika rata-
\end{abstract}


rata standar industri 35\% maka kondisi perusahaan dinilai sangat baik. Rasio aktivitas yang terdiri dari total asset turn over dan perputaran persediaan menunjukkan kinerja keuangan perusahaan berdasarkan laporan keuangan pada tahun 2014-2017 dalam keadaan baik. Rasio profitabilitas yang terdiri dari Return on Assets dinilai dalam keadaan yang baik karena kemampuan aktiva yang diinvestasikan untuk berputar dalam menghasilkan laba sangat tinggi. Kinerja keuangan perusahaan tergolong sangat baik, bila diukur dengan menggunakan return on assets.

Kata Kunci : Kinerja Keuangan, Rasio Likuiditas, Rasio Solvabilitas, Rasio Aktivitas, dan Rasio Profitabilitas. 


\section{PENDAHULUAN}

\section{A. Latar Belakang}

Sebuah perusahaan pada awalnya hanya memikirkan keuntungan yang besar dan cepat dengan melakukan apapun untuk mencapai target yang diinginkan tanpa memikirkan dampak dimasa yang akan datang. Tetapi lambat laun perusahaan juga menyadari bahwa setiap kegiatan yang dilakukan harus memperhitungkan risiko yang dihadapi.

Perkembangan posisi keuangan mempunyai arti yang sangat penting bagi perusahaan. Untuk melihat sehat tidaknya suatu perusahaan tidak hanya dapat dinilai dari keadaan fisiknya saja, misalnya dilihat dari gedung, pembangunan atau ekspansi. Faktor terpenting untuk dapat melihat perkembangan suatu perusahaan terletak dalam unsur keuangannya, karena dari unsur tersebut juga dapat mengevaluasi apakah kebijakan yang ditempuh suatu perusahaan sudah tepat atau belum, mengingat sudah begitu kompleksnya permasalahan yang dapat menyebabkan kebangkrutan dikarenakan banyaknya perusahaan yang akhirnya gulung tikar karena faktor keuangan yang tidak sehat.

Salah satu alat yang digunakan untuk mengetahui kondisi keuangan perusahaan dapat berwujud laporan keuangan. Laporan keuangan menyajikan gambaran mengenai posisi keuangan dari kinerja perusahaan dalam menghasilkan laba. Posisi keuangan perusahaan ditunjukkan dalam laporan neraca dan laporan laba rugi. Dalam laporan neraca kita dapat mengetahui kekayaan atau assets perusahaan yang dimiliki (sisi aktiva), dan dari sisi pasiva dapat kita ketahui darimana dana-dana untuk membiayai aktiva tersebut (dari modal sendiri atau hutang), sedangkan kinerja perusahaan dalam 
menghasilkan laba dapat kita lihat dari laporan laba rugi perusahaan. Data keuangan tersebut dianalisis lebih lanjut sehingga akan diperoleh informas yang dapat mendukung keputusan yang dibuat.

Perusahaan perlu melakukan analisis laporan keuangan karena laporan keuangan digunakan untuk menilai kinerja perusahaan dan digunakan untuk membandingkan kondisi perusahaan dari tahun sebelumnya dengan tahun sekarang apakah perusahaan tersebut meningkat atau tidak sehingga perusahaan mempertinbangkan keputusan yang akan diambil untuk tahun yang akan datang sesuai dengan kinerja perusahaannya. Perusahaan akan mencapai laba ketika pendapatan melebihi total biaya yang dikeluarkan. Jika laba perusahaan mengalami peningkatan dari tahun ke tahun, maka perusahaan tersebut dapat dikatakan mempunyai kinerja yang baik. Namun, laba yang besar bukan merupakan suatu ukuran mutlak kinerja keuangan perusahaan. Oleh Karena itu, diperlukan suatu teknik-teknik analisis, seperti analisis rasio keuangan.

Menurut Asian Development (APD),2018 (Kutipan dalam Daga,2021) Lembaga Keuangan Mikro (LKM). Menurut Asian Development Bank (ADB), lembaga keuangan mikro (microfinance) adalah lembaga yang menyediakan jasa penyimpanan (deposits), kredit (loans), pembayaran berbagai transaksi jasa (payment services) serta money transfers yang ditujukan bagi masyarakat miskin dan pengusaha kecil (insurance to poor and low-income households and their microenterprises). Sedangkan bentuk LKM dapat berupa: (1) lembaga formal misalnya bank desa dan koperasi, (2) lembaga semiformal misalnya organisasi non pemerintah, dan (3) sumber-sumber informal misalnya pelepas uang.

\section{B. Rumusan Masalah}


Adapun rumusan masalah dari penelitian ini, yaitu : Bagaimana analisis Kinerja Keuangan Pada PT. PEGADAIAN (Persero) tahun (2017-2020).

\section{Tujuan Penelitian}

Tujuan dilakukan penelitian ini adalah untuk mengetahui kinerja keuangan PT.Pegadaian (Persero) Cabang Talasalapang di Kota Makassar dilihat dari aspek likuiditas, solvabilitas, aktivitas dan profitabilitas. 


\section{TINJAUAN PUSTAKA}

\section{A. LANDASAN TEORI}

\section{Laporan Keuangan}

Menurut Hery (2012:2) Laporan keuangan adalah hasil dari proses akuntansi yang dapat digunakan sebagai alat untuk mengkomunikasikan data keuangan atau aktivitas perusahaan kepada pihak-pihak yang berkepentingan. Dengan kata lain sebagai alat informasi yang menghubungkan perusahaan dengan pihak-pihak yang berkepentingan, yang menunjukkan kondisi kesehatan keuangan perusahaan dan kinerja perusahaan. Menurut Kasmir (2015:7) "Laporan keuangan adalah laporan yang menunjukkan kondisi keuangan perusahaan pada saat ini atau dalam suatu periode tertentu"

\section{Analisis Laporan Keuangan}

Menurut Harahap (2015:190) bahwa Analisis laporan keuangan adalah menguraikan pos pos laporan keuangan menjadi unit informasi yang lebih kecil dan melihat hubungannya yang

bersifat signifikan atau yang mempunyai makna antara satu dengan yang lain baik antara data kuantitatif maupun data non-kuantitatif dengan tujuan untuk mengetahui kondisi keuangan lebih dalam yang sangat penting dalam proses menghasilkan keputusan yang tepat.

Menurut Sujarweni (2017:35) menyatakan bahwa analisis laporan keuangan adalah suatu analisis yang dilakukan untuk melihat pada suatu keadaan keuangan perusahaan, bagaimana pencapaian keberhasilan perusahaan masa lalu, saat ini, dan 
prediksi dimasa mendatang, analisis laporan keuangan tersebut akan digunakan dasar pengambilan keputusan oleh pihak-pihak yang berkepentingan. Tujuan analisis laporan keuangan merupakan alat yang sangat penting untuk memperoleh informasi sehubungan dengan posisi keuangan dan hasil-hasil yang telah dicapai perusahaan yang bersangkutan. Data keuangan tersebut akan lebih berarti bagi pihak-pihak yang berkepentingan apabila data tersebut diperbandingkan untuk dua periode atau lebih, dan dianalisis lebihh lanjut sehingga akan dapat diperoleh data yang akan dapat mendukung keputusan yang akan diambil.

\section{Kinerja Keuangan}

Menurut Fahmi (2014:239) "kinerja keuangan adalah suatu analisis yang dilakukan untuk melihat sejauh mana suatu perusahaan telah melaksanakan dengan menggunakan aturan-aturan pelaksanaan keuangan secara baik dan benar". Menurut Martono dan Harjito (2011:52) "kinerja keuangan suatu perusahaan sangat bermanfaat bagi berbagai pihak seperti investor, kreditur, analisis, konsultan keuangan, pialang, pemerintah, dan pihak manajemen sendiri".

Pengukuran kinerja digunakan perusahaan untuk melakukan perbaikan diatas kegiatan operasionalnya agar dapat bersaing dengan perusahaan lain. Analisis kinerja keuangan merupakan proses pengkajian secara kritis terhadap review data, menghitung, mengukur, menginterprestasi, dan member solusi terhadap keuangan perusahaan pada suatu periode tertentu.

\section{Analisis Rasio Keuangan}


Mengadakan analisis terhadap hubungan dari berbagai pos dalam suatu laporan keuangan merupakan dasar untuk bisa menginterpretasikan kondisi keuangan dan hasil operasi dalam suatu perusahaan. Untuk mengadakan interpretasi tersebut tentunya seorang analisis memerlukan suatu ukuran. Ukuran yang umum digunakan untuk mengetahui kinerja perusahaan dibidang keuangan adalah analisis keuangan.

Menurut Kasmir (2017:104), "rasio keuangan merupakan kegiatan membandingkan angka-angka yang ada dalam laporan keuangan dengan cara membagi satu angka dengan angka lainnya". Menurut Horne (2009:202), "rasio keuangan (financial ratio) didefinisikan sebagai: "sebuah indeks yang menghubungkan dua angka akuntansi dan diperoleh dengan membagi satu angka dengan angka lainnya".

\section{Penelitian Terdahulu}

Sebagai bahan perbandingan penulis mempelajari dari penelitian sebelumnya yang meneliti kinerja keuangan. Salah satu penelitian yang dilakukan oleh Mustakim (2018), ia melakukan penelitian tentang Analisis profitabilitas, likuiditas, aktivitas, dan solvabilitas untuk mengukur kinerja keuangan pada PT.Pegadaian (Persero) Cabang Talasalapang di Kota Makassar selama lima tahun terakhir (2013-2017). Hasil penelitian menunjukkan bahwa PT. Pegadaian (Persero) Cabang Talasalapang di Kota Makassar selama lima tahun terakhir mengalami peningkatan, pengukuran kinerja keuangan dengan menggunakan rasio profitabilitas yang terdiri dari Return on Assets dinilai dalam keadaan yang baik karena kemampuan aktiva yang diinvestasikan untuk berputar dalam menghasilkan laba sangat tinggi dan dengan Return on Equity dinilai dalam keadaan yang baik karena kemampuan ekuitas/modal yang digunakan untuk 
menghasilkan laba sangat tinggi. Pengukuran kinerja keuangan dengan menggunakan rasio

likuiditas yang terdiri dari Current Ratio dinilai sangat baik karena kemampuan perusahaan dalam melunasi hutang lancar lebih dari 200\% sedangkan dengan Quick Ratio selama tahun 2013-2017 mengalami fluktuasi, nilai ini dianggap masih aman. Nilai Quick Ratio yang diperoleh lebih dari 100\%, yang menunjukkan kemampuan perusahaan untuk melunasi hutang lancar dengan aktiva lancar setelah dikurang persediaan dalam kondisi baik. Pengukuran kinerja keuangan menggunakan rasio solvabilitas dengan Total Assets to Debt Ratio menunjukkan fluktuasi dari tahun 20132017 dan dapat dikatakan solvabilitas karena kemampuan perusahaan dalam memenuhi semua hutang dengan aktiva dapat terpenuhi, meskipun dalam tiga tahun terakhirnya mengalami penurunan.

Selanjutnya penelitian Pattanggau (2018) dengan judul analisis kinerja keuangan PT. Pegadaian (Persero) dan entitas anak perusahaan berdasarkan KEPMEN BUMN nomor KEP- 100/MBU/2002 (periode 2013-2017). Hasil penelitian ini adalah kinerja perusahaan bila diukur secara keseluruhan menunjukkan kinerja keuangan yang termasuk dalam kategori sehat. Kinerja keuangan rasio likuiditas bila diukur menggunakan analisis rasio lancar menunjukkan hasil sangat sehat, bila diukur menggunakan rasio kas meunjukkan hasil tidak sehat. Kinerja keuangan rasio solvabilitas bila diukur menggunakan rasio modal sendiri terhadap total aktiva menunjukkan kinerja yang kurang sehat. Kinerja keuangan aktivitas bila diukur menggunakan rasio collection periods menunjukkan kinerja yang sehat. Kinerja keuangan proofitabilitas bila diukur menggunakan rasio ROE menunjukkan kinerja yang sangat sehat, bila diukurmenggunakan rasio $\mathrm{ROI}$ menunjukkan kinerja yang sehat. 
Penelitian Mapantau (2017) dengan judul analisis laporan keuangan berdasarkan metode vertikal-horizontal dan rasio keuangan untuk mengevaluasi kinerja keuangan perbankan pada bank BUMN (periode 2010-2012). Hasil penelitian dengan menggunakan analisis vertikal menunjukkan bahwa indeks neraca dan laporan laba rugi Bank BUMN sudah optimal sedangkan laporan arus kas Bank BUMN cenderung tidak optimal. Dengan demikian pihak bank diharapkan lebih memperhatikan arus kas untuk meningkatkan kinerja keuangannya. Hasil penelitian denngan menggunakan analisis horizontal menunjukkan bahwa kinerja bank BUMN selama periode 2010-2012 berfluktuatif. Hasil penelitian selanjutnya dengan menggunakan analisis rasio keuangan berdasarkan tingkat kesehatan $\mathrm{BI}$, menggunakan rasio $\mathrm{CA}-\mathrm{EL}$ untuk melihat kondisi kesehatan bank, menunjukkan rasio CAR, BOPO,NPL, dan ROA keempat Bank BUMN dalam kondisi sehat, meskipun pada tahun 2010 rasio ROA bank BUMN Indoonesia berada di bawah standar namun tahun berikutnya rasio tersebut kembali sehat, sedangkan rasio LDR hanya bank tabungan Negara yang mematuhi standar likuiditas yang ditetapkan oleh bank Indonesia sedangkan ketiga bank lainnya berada dibawah standar kesehatan bank Indonesia. Dengan demikian diharapkan Bank Mandiri, BNI, dan BRI dapat meningkatkan likuiditasnya agar mencapai tingkat kesehatan BI melalui perbaikan-perbaikan infrastruktur khususnya di bidang perkreditan, dan lebih meningkatkan kualitas pelayanan dan promo untuk meningkatkan dana pihak ketiga.

Nur (2018) dengan judul analisis laporan keuangan dalam menilai kinerja keuangan industri semen yang terdaftar di BEI (studi kasus PT. Indocement tunggal prakasa TBK). kinerja keuangan PT Indocement tunggal prakarsa Tbk setiap tahunnya 
terlihat dengan rasio yang berfluktiatif, ini disebabkan adanya kenaikan maupun penurunan pada pos-pos laporan keuangan, misalkan pada penjualan, persediaan, laba, dan lainnya.

\section{B. KERANGKA PIKIR}

PT. Pegadaian (Persero)

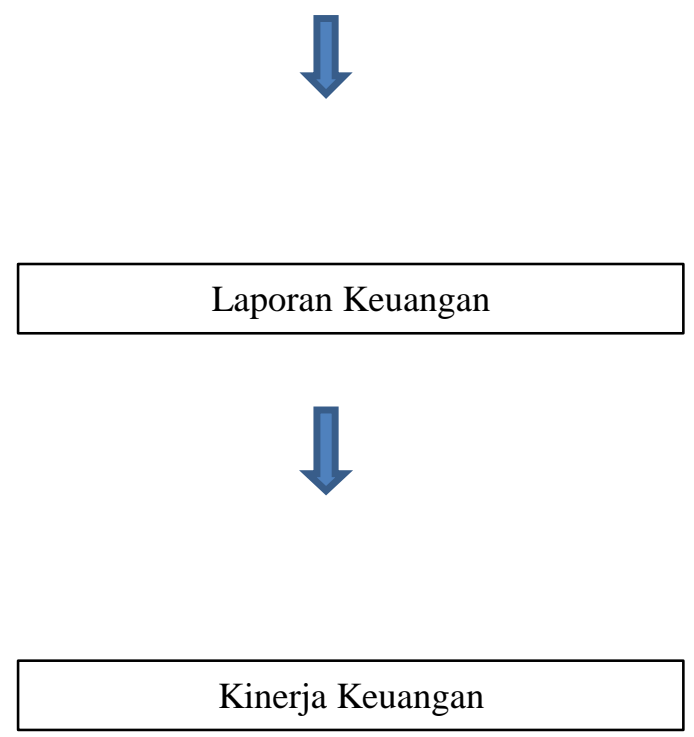




\section{METODE PENELITIAN}

\section{A. Lokasi dan Waktu penelitian}

Lokasi dan waktu penelitian ini dilakukan pada perusahaan PT. PEGADAIAN (Persero) Cabang Talasalapang Di Kota Makassar Dengan waktu penelitian selama 1 bulan.

\section{B. Jenis dan sumber data}

Jenis data yang yang digunakan dalam penelitian ini adalah data sekunder yang bersifat kuantitatif. Menurut Sangadji dan Sopiah (2010:190) "data sekunder adalah data yang diterbitkan atau digunakan oleh organisasi yang bukan pengolahnya". Data kuantitatif adalah data yang berupa angka atau bilangan, yaitu laporan keuangan perusahaan yang meliputi laporan neraca dan laporan laba rugi perusahaan.

\section{Populasi dan sampel}

1. Populasi

Menurut Sugiyono (2009:80), "populasi adalah wilayah generalisasi yang terdiri dari objek atau subjek yang mempunyai kualitas dan karakteristik tertentu yang ditetapkan oleh peneliti untuk dipelajari dan kemudian ditarik kesimpulannya". Populasi dalam penelitian ini adalah laporan keuangan pada PT. Pegadaian (Persero) Cabang Talasalapang di Kota Makassar selama empat tahun terakhir (2017-2020).

2. Sampel

Menurut Sangadji dan Sopiah (2010:186) "sampel adalah bagian dari jumlah dan karakteristik yang dimiliki oleh populasi”. Adapun sampel dalam penelitian ini adalah Neraca dan Lapooran Laba Rugi PT.Pegadaian (Persero) Cabang Talasalapang di Kota Makassar periode 2017-2020. 


\section{Teknik pengumpulan data}

Metode pengumpulan data yang digunakan penulis dengan cara sebagai berikut:

\section{Dokumentasi}

Dokumen yaitu pengumpulan data dengan mencatat data dari dokumendokumen pegadaian yang dibutuhkan dalam penelitian. Dalam penelitian ini, data-data yang diperoleh dengan menggunakan metode dokumentasi adalah sejarah, struktur organisasi, laporan realisasi anggaran pegadaian mencakup anggaran biaya operasional dan anggaran pendapatan, dan laporan keuangan mencakup laporan laba rugi dan laporan neraca.

\section{Wawancara}

Wawancara yaitu mengadakan pengumpulan data dengan cara menanyakan langsungkepada pimpinan atau karyawan yang berkompoten dengan masalah yang dibahas.

\section{E. Teknik Analisis Data}

Dalam penelitian ini dilakukan pengukuran menggunakan analisis rasio keuangan secaraumum yang dilakukan pada laporan keuangan pegadaian, yaitu:

1. Likuiditas

a. Current ratio (Rasio lancar)

$$
\text { Current ratio }=\frac{\text { Aktiva lacar }}{\text { Hutang lancar }} \times 100
$$


b. Quick ratio (Rasio cepat)

$$
\begin{aligned}
& \text { Quick ratio }=\text { Aktiva lancar-persediaan } \\
& \text { Utang lancar } \\
& \times 10
\end{aligned}
$$

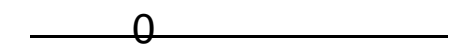

c. Cash ratio (Rasio kas)

$$
\text { Cash ratio }=\frac{\text { Kas+Bank }}{\text { Hutang lancar }} \times 100
$$

2. Solvabilitas

$$
\begin{array}{ll}
\text { Debt to asset } & \text { Total utang } \\
\text { ratio }= & \text { Total aset } \\
& \times 100
\end{array}
$$

3. Aktivitas

a. Total assets turn over (TATO)

$$
\text { TATO }=\frac{\text { Total }}{\text { pendapatan }}
$$

b. Perputaran persediaan (Inventory turn over) 


\section{Total}

pendapatanPerputaran persediaan=

Total persediaan

4. Profitabilitas

a. Hasil pengembalian assets (Return on assets/ROA)

Return on asset Laba Setelah Pajak

$(\mathrm{ROA})=\quad$ Total aktiva

$\times 10$

0 


\section{PENUTUP}

\section{Kesimpulan}

Berdasarkan hasil analisis yang telah diuraikan sebelumnya, maka dapat ditarik kesimpulan sebagai berikut:

1. Berdasarkan analisis rasio Likuiditas PT Pegadaian (Persero) Cabang Talasalapang di Kota Makassar pada tahun 2017-2020 Current Ratio dinilai sangat baik karena kemampuan perusahaan dalam melunasi hutang lancar melebihi dari standar industri. Sedangkan nilai Quick Ratio yang diperoleh selama tahun 2017-2020 melebih dari standar rasio yakni 150\% yang menunjukkan kemampuan perusahaan untuk melunasi hutang lancar dengan aktiva lancar setelah dikurang persediaan dalam kondisi baik. Sementara nilai Cash Ratio pada tahun 2018 dinilai kurang baik karena dibawah rata-rata standar industri disebabkan oleh meningkatnya hutang lancar dibandingkan kas pada tahun sebelumnya. Kinerja keuangan perusahaan berdasarkan laporan keuangan bila diukur menggunakan current ratio dan quick ratio menunjukkan kinerja keuangan sangat baik.

2. Berdasarkan analisis rasio solvabilitas PT. Pegadaian (Persero) Cabang Talasalapang di Kota Makassar Debt to Assets Ratio dari tahun 2017-2020 dapat dikatakan cukup baik karena kemampuan perusahaan dalam memenuhi semua hutang dengan aktiva dapat terpenuhi, menunjukkan kinerja keuangan perusahaan cukup baik.

3. Berdasarkan analisis rasio aktivitas PT. Pegadaian (Persero) Cabang 
Talasalapang di Kota Makassar Total Assets Turnover tahun 2014-2017 dinilai sangat baik kerena kemampuan perusahaan dalam mendapatkan pendapatan dari seluruh total aktiva melebihi standar industri. Sedangkan Inventory Turnover PT. Pegadaian (Persero) Cabang Talasalapang di Kota Makassar tahun 20172020 dinilai sangat baik karena kemampuan perusahaan dalam menggunakan dana yang ditanam dalam sediaan untuk berputar cukup tinggi. Nilai Inventory Turnover lebih tinggi dari rata-rata standar industri. Kinerja keuangan perusahaan berdasarkan laporan keuangan pada tahun 2017- 2020 menunjukkan dalam keadaan baik.

4. Berdasarkan analisis rasio profitabilitas pada tahun 2017-2020 Return on Assets PT. Pegadaian (Persero) Cabang Talasalapang di Kota Makassar dinilai dalam keadaan yang baik karena kemampuan aktiva yang diinvestasikan untuk berputar dalam menghasilkan laba sangat tinggi. Maka kinerja keuangan perusahaan menunjukkan dalam keadaan baik.

\section{Saran}

Mengacu pada kesimpulan di atas, maka dapat diajukan beberapa saran sebagai berikut :

1. Manajemen PT Pegadaian (Persero) Cabang Talasalapang di Kota Makassar, diharapkan dapat memperbaiki rasio likuiditas terutama cash rasio pada tahun 2018 yang masih dibawah rata-rata standar industri. Manajemen perusahaan harus mengurangi jumlah hutang lancar dan meningkatkan rata-rata kas perusahaan.

2. Manajemen PT Pegadaian (Persero) Cabang Talasalapang di Kota Makassar, harus bisa mempertahankan dan meningkatkan lagi rasio profitabilitas, aktivitas dan solvabilitasnya karena sudah mencapai rata-rata standar industri perusahaan. 
3. Untuk peneliti selanjutnya diharapkan untuk menambah tahun serta menambahkan rasio- rasio yang lain untuk mengukur kinerja keuangan perusahaan agar hasil analisis yang diperoleh dapat lebih baik. 


\section{DAFTAR PUSTAKA}

Fahmi Irham. 2014. Analisis Laporan Keuangan. Edisi Keempat. Bandung: Alfabeta.

Harahap. 2015. Analisis Kritis Atas Laporan Keuangan. Cetakan Kedua Belas. Jakarta.

Rajawali Pers.

Harjito Agus Dan Martono. 2011. Manajemen Keuangan. Edisi Kedua. Penerbit Ekonisia Universitas Islam Indonesia. Yogyakarta.

Hery. 2012. Akuntansi Keuangan Menengah 1.Jakarta. PT Bumi Aksara. Kasmir. 2008.

Manajemen Perbankan. Jakarta : PT. Raja Grafindo Persada

2015. Analisis Laporan Keuangan. Jakarta. Rajawali Pers

2017. Analisis Laporan Keuangan. Cetakan Kesepuluh. Jakarta. Rajawali Pers.

Sangadji, Etta Mamang. 2010. Metode Penelitian - Pendakatan Praktis Dalam Penelitian.

Edisi 1.Yogyakarta. C.V Andi Offset.

Sugiyono. 2009. Metode Penelitian Kuantitatif, Kualitatif, Dan R\&D:CV. Alphabet.

Sujarweni. 2017. Analisis Laporan Keuangan Teori, Aplikasi, Dan Hasil Penelitian.

Yogyakarta.

Pustaka Baru Press.

Ekawati. 2016. Analisis Rasio Keuangan Dalam Menilai Kinerja Keuangan Pada PT

Pegadaian (Persero) Cabang Pinrang.Jurnal: Riset. Vol 4. Edisi V.April

Daga, R., \& Taufiq, H. I. (2018). Persepsi Pengusaha Mikro Terhadap Lembaga

Keuangan Mikro di Makassar. 
Mutiara Nur Rahmah Dan Komariah, 2016. Analisis Laporan Keuangan Dalam Menilai Kinerja Keuangan Industri Semen Yang Terdaftar Di BEI (Study Kasus PT Indocement Tunggal Prakarsa Tbk. Jurnal Online Insan Akuntan Vol 1 No 1. Bekasi Timur. Akademi Akuntansi Bina Insani. E-ISSN: 2528-0163. Juni

Pattanggau, Yohana Martin Dan Rahim, Abdul Rahman. 2016. Analisis Kinerja Keuangan PT. Pegadaian (Persero) Dan Entitas Anak Perusahaan Berdasarkan KEPMEN BUMN No KEP-100/MBU/2002 (Periode 2011-2015. Jurnal Kompetiti Veness. Vol 10 No.2. ISSN:1978-3035. Unismuh Makassar. Desember. 